\title{
Land Use and Land Cover Spatial Distribution in Pondicherry Coastal Region Using Remote Sensing and GIS Techniques with Special Reference to Aquaculture Development
}

\author{
Dr. I. Raja Rajasri Pramila Devi \\ Assistant Professor \\ Department of M.Sc. Advanced Zoology \& Biotechnology \\ Guru Nanak College, Chennai, Tamil Nadu, India
}

\begin{abstract}
The remote sensing with GIS plays a major role in land use land cover changes. The satellite imageries of IRS 1C LISS III (1998), IRS 1D LISS III (2000) and P6 (2008 $\&$ 2014) have been used for land use and land cover map preparation. The change detection study has been carried out in a GIS environment. The results observed through many research studies have showed agriculture land was reduced from 10,968 ha to 6214.24 ha due to rapid industrialization and settlements. Pondicherry having a coastal line of $45 \mathrm{~km}$ also has had significant potential in fisheries. Interestingly out of 800 ha of potential fisheries area, only 138 ha of aquaculture land is utilized. Hence, commercial aquaculture can be encouraged in this area, as it should not affect the other area. It is a good economic source for local people. Moreover, the socio-economic impacts on vegetation, with settlement, plantation, aquaculture, agriculture, fallow lands and marshy lands have also been identified. The present study will be useful for policy makers towards further development and management.
\end{abstract}

Keywords: Land Use, Land Cover, Changes, Coastal, Aquaculture, Agriculture, Remote Sensing, Pondicherry.

\section{Introduction}

Pondicherry has been experiencing a significant shift in its economy. The reason being economic activity has moved away from agriculture to industries and services. Land is the most significant among the natural resources of the country and is being used by people for various purposes. The basic requirement of human society is food and most of the inhabitants depend on agriculture for their livelihood. Overpopulation has resulted in increasing the pressure on coastal land which accelerated increase in land value and the diversity of the land uses. Land is one of the important phenomena, owing to its progressive or cyclic changes due to dynamic processes and it supports a variety of economic activities such as 
industrial, commercial, recreation, etc. (Thanikachallam, 2005). Despite the negative overall growth in agriculture and aquaculture, it remains an important source of livelihood for Pondicherry people and must register significant growth rates in order to improve the living of those engaged in it. Thus, in order to examine how this may be brought about, it is necessary to identify both the constraints faced by agriculture and its potential information extracted by integrating remote sensing data with conventional data can provide the picture about coastal land use. Furthermore, such an integrated data and information could be obtained only through GIS and Remote Sensing tools. It is to be noted that by using these tools we can accurately assess the land, water bodies, socio-economic and human resources (Krishnakumar, et al. 2011). The land use maps were prepared for the study area for four different years viz. 1998, 2000, 2008 and 2014 using IRS IC, ID and P6 data. The maps of four different years were prepared so as to identify the changes that have occurred in the Land use categories. In the present study multi temporal satellite data were used to study the changes in land use and land cover changes for the aforesaid periods.

\section{Literature Review}

The remote sensing application plays a vital role in aquaculture studies it is important to review the research carried out during the past on the land use mapping coupled with their usage and GIS applications. A research study by Barlet and Klemas have showed that remote sensing is useful for delineation of wetlands boundaries and the areal extent Spectral contrast between species of interest can be modified by intraspecific variability in canopy and leaf characteristics the distribution of species can be mapped on composition (Barlet \& Klemas, 1979).

The distribution of species can be mapped on composition of species acquired through remote sensing which can be used to make an inference concerning tidal and salinity regimes and habitats available for estuaries and terrestrial fauna (Barlet and Klemas 1979). Howrah in 1984 has described seasonal and long-term changes. He has used chromaticity analysis for suspended sediment concentration measurement from landsat data Methodology for change detection includes, the stages of background preparations, loading the data, preprocessing, image enhancement, classification, post classification, change and signature file extensions (Howrah, 1984). A study by Kapetsky in 1987 has used Remote Sensing (Landsat TM CCT) and GIS as a tool to plan for aquaculture expansion in Gulf of Nicoya, Coasta Rica and has found GIS to be a very useful tool for the aquaculture planning. The mapping up to a scale 1:250000 are possible as mentioned by Anderson in 1973.

The IRS data was visually as well as digitally, analyzed for evaluating, their suitability for coastal wetland mapping of the Gulf of Kachch The distinction between nonvegetated categories was not sharp when LISS-I data was used as compared to MSS 
data The identification of various wetland features using LISS-I and TM data was found to be comparable in both types of analysis as explained by Nayak in 1988. Also, Raine studied current land use and changes in land use over time in coastal zone of Thailand and they quantified the land use in coastal zone and investigated the changes in land use practices between the years of 1953, 1975 and 1991 in Thailand (Raine, 1994).

A study conducted by Krishnamoorthy in 1995 on application of remote sensing and geographic information system in survey and site selection for aquaculture practices revealed that aquaculture suitable for farming can be effectively identified by macro level land survey through integration of remote sensing, conventional data and GIS. Yet another research study carried out by Gupta in 1997 has studied the aquaculture site selection using remote sensing and GIS and its impact on the environment in South Gujarat He has used Arc/Info GIS packages, for aquaculture site selection and discussed.

The various issues such as pollution and mangrove conservation related to aquaculture. In addition to this, Krishnakumar et al. in 2011 have studied that the land use/Land cover changes in Nagapattinam coastal area and revealed that satellite data has the unique capability to detect the changes in land use / land cover quickly and accurately and the data is very useful and effective for getting results of temporal changes of land. Anusuya and Emayavaramban in 2017 have studied that land use and land cover changes mapping has given differentiation of research through various investigation.

\section{Need \& Relevance}

This study will give a clear picture of current status of environmental impact and land use and land cover changes of Pondicherry coastal area. From this study we can prepare a model of sustainable development of land utilization. This study highlights the impact of industries and ecologically sensitive area for preparing coastal management plans. Moreover, the coastal land use maps are useful for identifying areas under erosion and critical habitat. It is important to note that explosive growth of the industry adversely affect the environment, ecosystem and degrade man's economy and recreation facilities. This problem has become crucial in the recent years and only alternative is the implication of EIA concepts to evolve environmental management strategies for optimum use of a land area without disturbing the natural equilibrium of the ecosystem. As growth continues, the landscape is altered. The forests, agriculture and farmlands are converted and developed as business and residential areas.

Land use is a product of interactions between cultural and physical needs of society and the natural potential of land. The land cover change has long been viewed as a continuing process with periods of rapid change. Improper land use often causes 
various forms of environmental degradations. Hence, for sustainable utilization of the land ecosystem, it is essential to know the nature, characteristics, extent and location of soil resources, productivity, suitability and limitations for various land uses. Recently, several international agencies, including Food and Agricultural Organization (FAO) and United National Environmental Protection (UNEP), have initiated a discussion on the subject of Environmental Impact Assessment (EIA) and land use/cover classification and databases and have commissioned preparatory studies for the purpose of rectifying the situation.

\section{Objectives}

$>$ To identify and delineate the various land use categories from remote sensed data using visual interpretation over the period of ten years (1998-2014)

$>$ To identify appropriate monitoring strategies to track impacts and provide an early warning system

$>$ To suggest and recommend suitable measures for sustainability

\section{Methodology}

\section{Profile of Study area}

Pondicherry now referred to as 'Puducherry', which means new village. The Pondicherry district is located on the Coromandal Coast between $11^{\circ} 45^{\prime}$ and $79^{\circ}$ $52^{\prime}$ E longitude. It is bounded on the east by Bay of Bengal and Tamil Nadu state on its other three sides. It is also the capital with the same name and comprises of three other enclaves including Karaikal in Tamil Nadu, Yanam in Andhra Pradesh and Mahe in Kerala. The coast is of curved in nature. Some beach ridge complexes at $3 \mathrm{~m}$ and $5 \mathrm{~m}$ above sea level are seen, wherein a submerged shoreline is indicated by the presence of skeletal sands.

\section{Data Material \& Software Support}

\section{Data Used}

\section{a. Primary Data}

IRS 1D LISS III and P6 data of 1998, 2000, 2008 and 2014 are used for Pondicherry.

\section{b. Secondary Data}

Survey of India toposheets No. 57P/16 and 58M/9 \& 10, on 1:50,000 scales are used for Pondicherry. 


\section{c. Software Support}

In order to identify and transform the information recorded on the IRS 1C,1D images and SOI toposheets, computer with ERDAS image processing software and ArcGIS, Arc view packages were used.

\section{Procedures \& Standardization}

Rectification has been done for the primary and secondary data.

* Base map was prepared for Pondicherry using NRSA Satellite data.

- Digitizing the thematic maps and derived maps using GIS software (ARC/Info).

* Area calculation and Validation have been carried out with the field-oriented ground truth collection.

Final Land use maps were prepared for different years.

The methodology adopted for study area is indicated in Fig. 1.

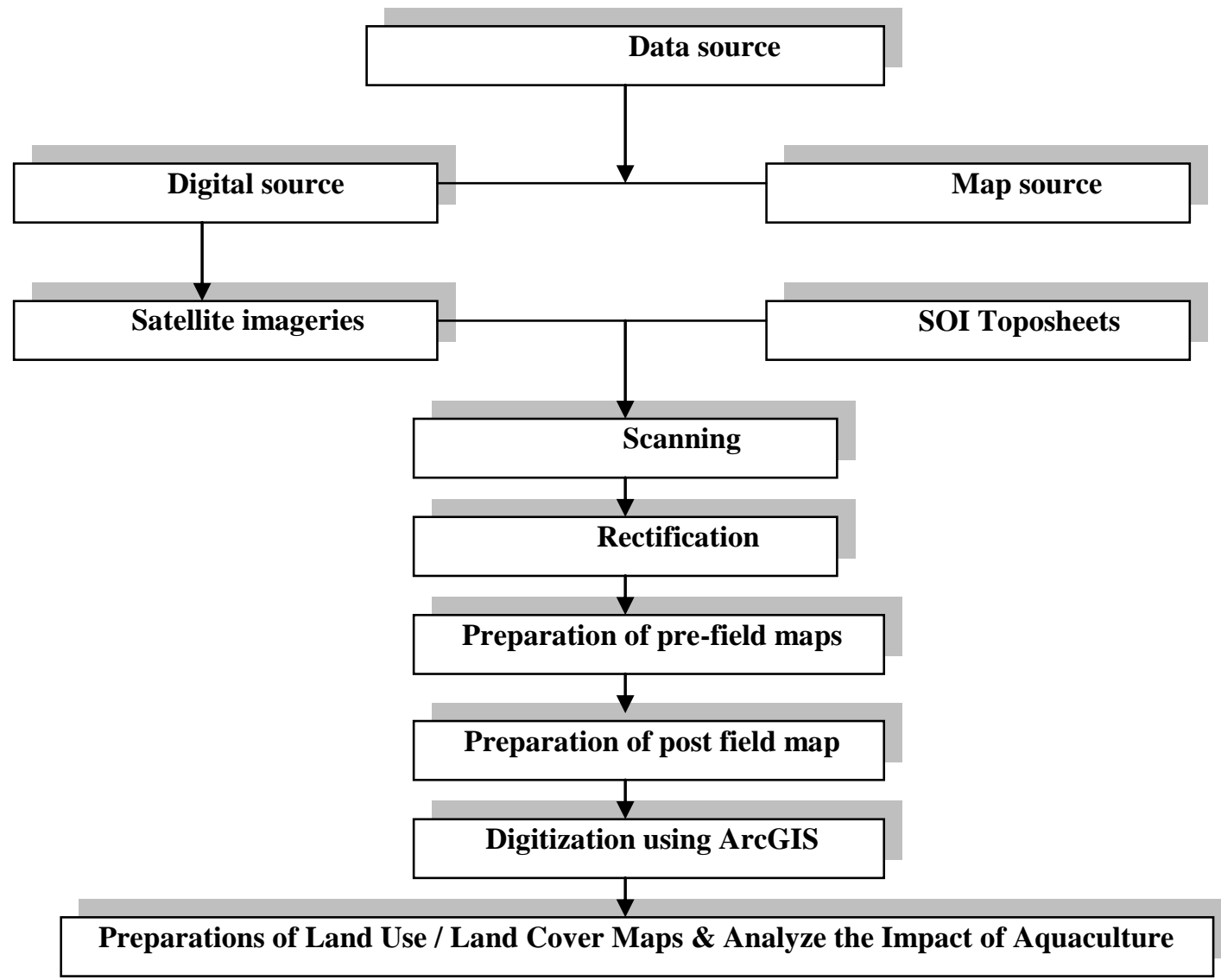

Fig. 1 Flow Chart for Methodology 


\section{Results \& Discussion}

In the present study multi temporal satellite data were used to study the changes in land use / land cover for the period of 1998, 2000 and 2008 using IRS 1C, 1D and P6 data. The maps for three different years (Fig 2 to Fig 5) were prepared so as to identify the changes that have occurred in the Land use categories. Maps were interpreted in order to compare the boundaries of land use classes from which the difference were calculated accordingly.

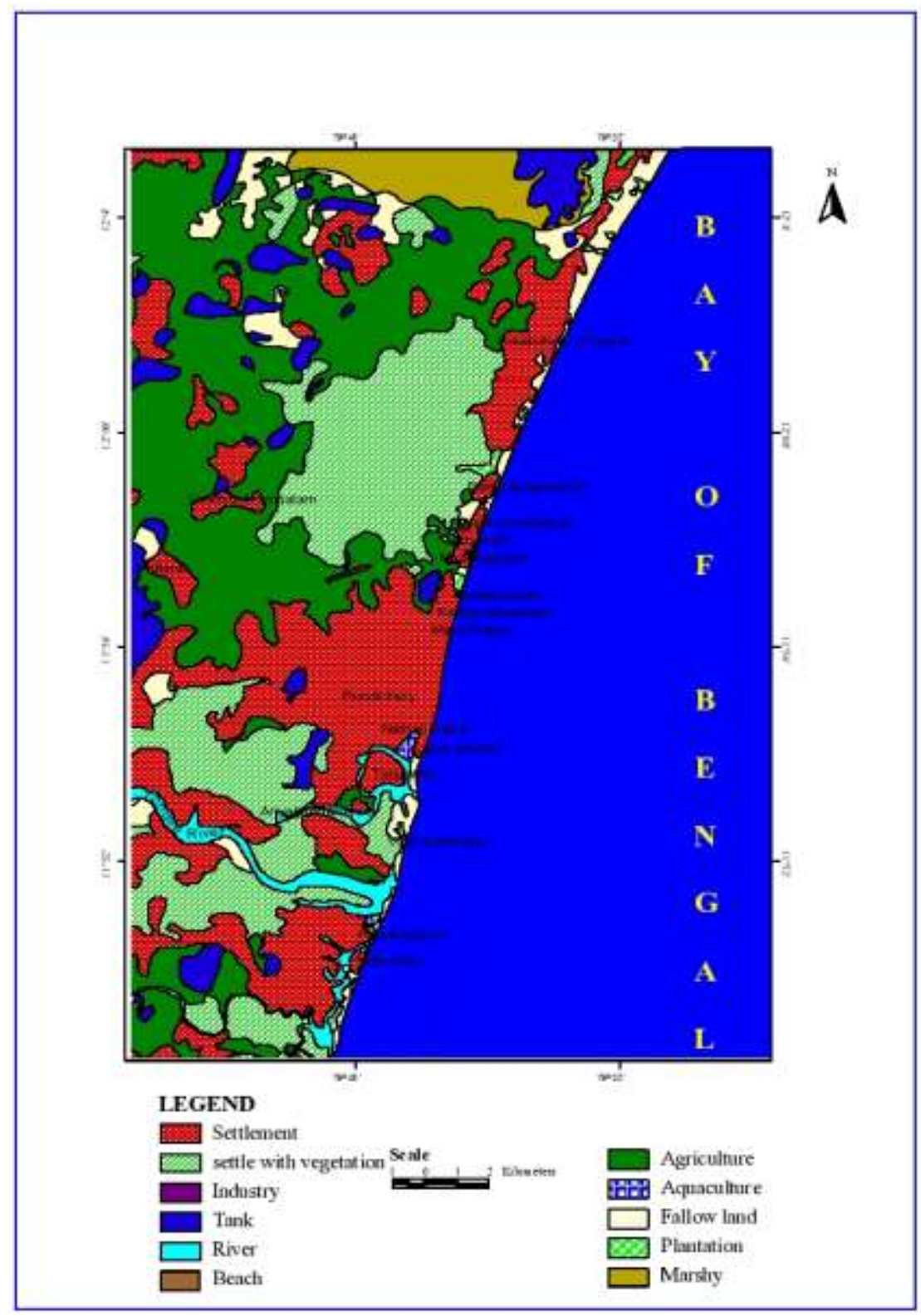

Figure 2: Land Use / Land Cover Map of Pondicherry in 1998 
Holistic Research Perspectives Vol.5

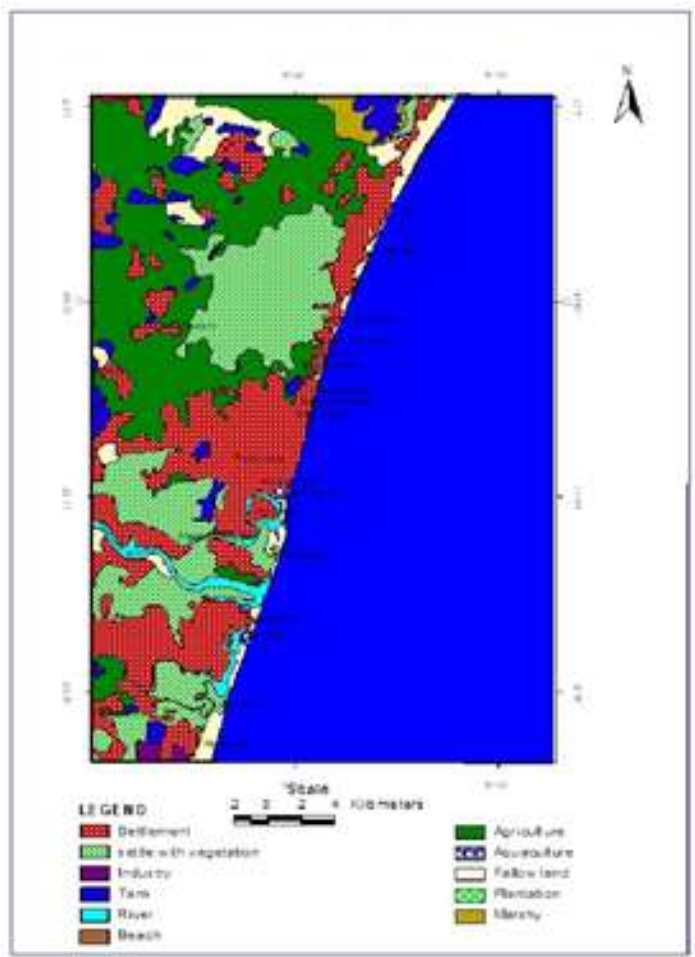

Figure 3: Land Use / Land Cover Mapping of Pondicherry in 2000

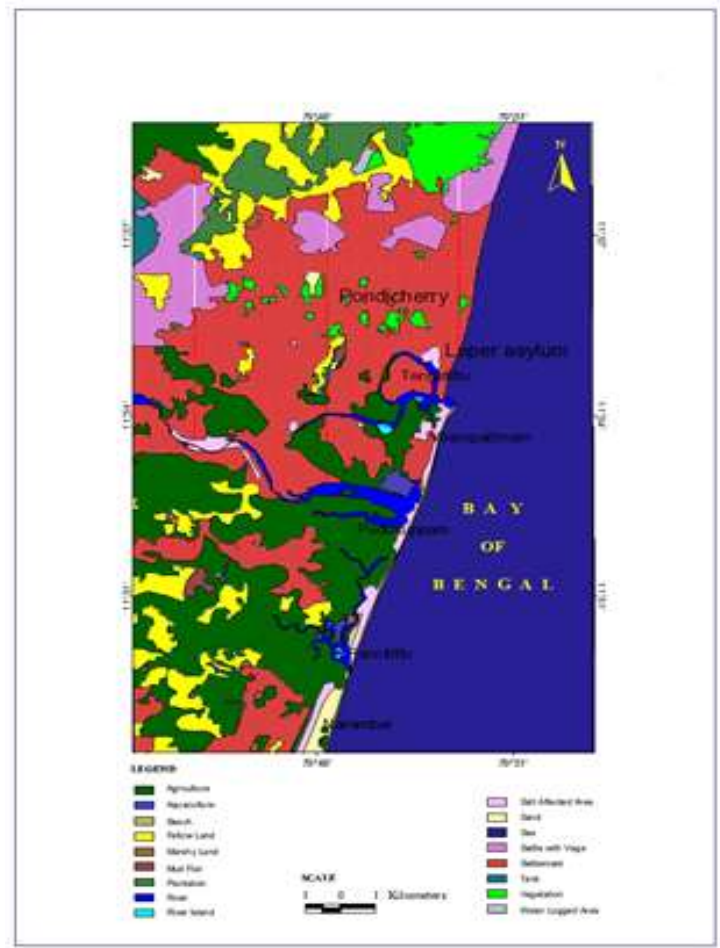

Figure 4: Land Use / Land Cover Map of Pondicherry in 2008 


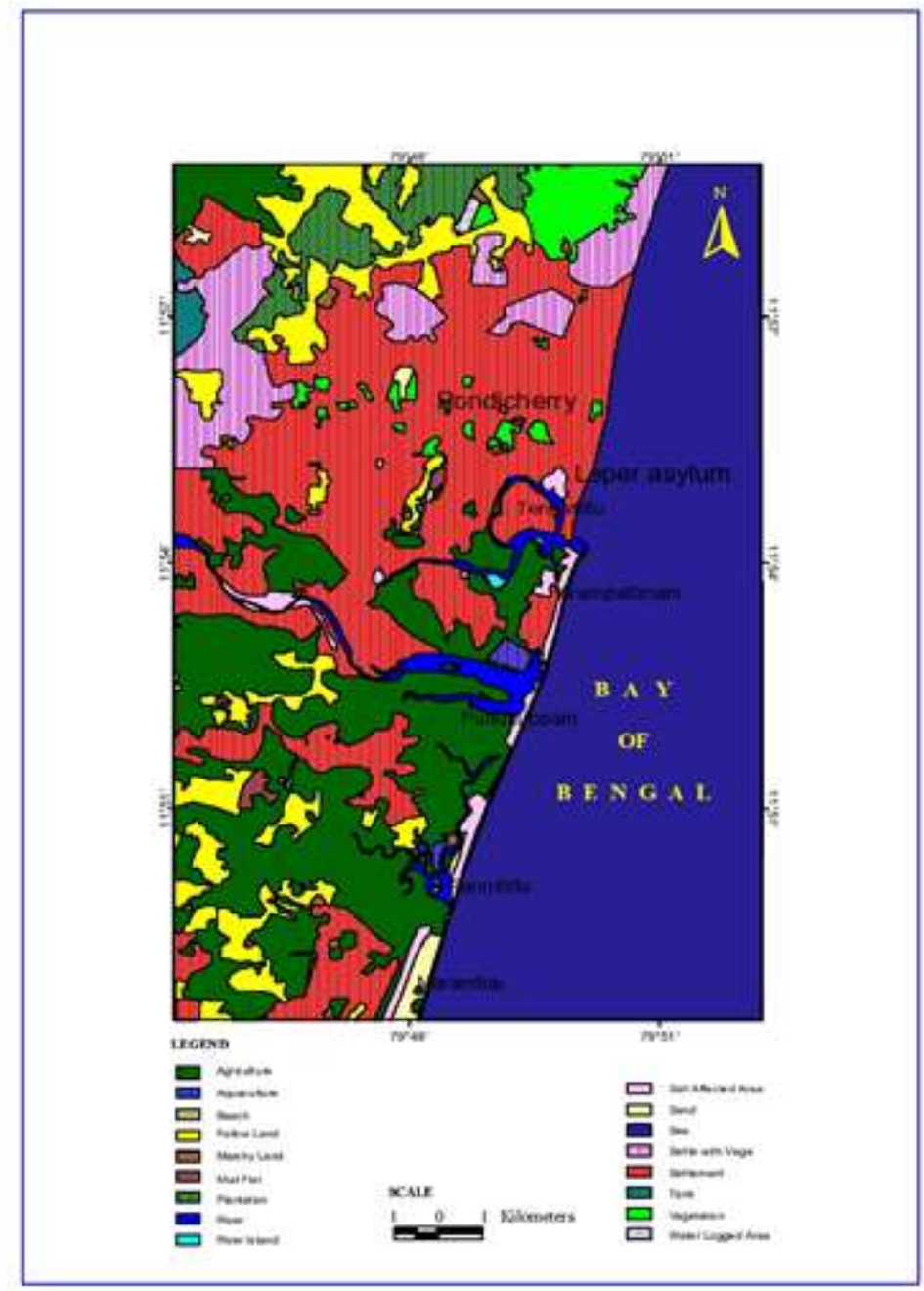

\section{Figure 5: Land Use / Land Cover Map of Pondicherry in 2014}

\section{Agriculture}

From the land use maps prepared during 1998 as indicated in above Fig 2 it can be observed that agriculture occupied 10,968.9 ha (Table 1) and subsequently, during 2014 the area occupied by agriculture was drastically reduced to 6214.24 ha (Table 3 ). This change is due to the urban and industrial development, which is the main problem in this area. Another factor is increasing population rate, which reduces the agriculture area. The agricultural land conversion is the most important impact and it also affects the crop production in Pondicherry. Most of the agriculture area converted to residential area, wherein similar research studies in this area have been conducted by Nagamani and Ramachandran in 2003. In 2011 Krishnakumar et al. conducted similar study in Nagapattinam coastal area, wherein they revealed that there are a number of socio-economic and ecological consequences of land use 
changes in Pondicherry. It has been found that the reduction in agriculture labour force and population growth are the most important human driving forces. Moreover, the population growth, due to natural increase and migration allows various land use features to be easily converted and developed into housing estate, townships, industrial estates and recreational facilities. Such developmental processes cause an increase in the education level, while simultaneously causing a decrease in agricultural labour force (Anusuya \& Emayavaramban, 2017). The most important and immediate impact of paddy land conversion is the adverse effect on rice production in the area and socio-economic conditions of the farmers and farm workers. There are more than nine lakh farm workers in Pondicherry, who get their income mainly from paddy cultivation. There should be a mechanism to conserve the existing paddy lands and also to implement an action program for increasing the production and productivity of paddy by providing essential science and technology input.

Table-1 Land Use and Land Cover Area Calculations in 1998 for Pondicherry

\begin{tabular}{|c|c|}
\hline Categories & Area (in ha) \\
\hline Agricultural Land & 10,968 \\
\hline Salt Pan & 159.208 \\
\hline Settlement with Vegetation & 9189 \\
\hline Settlement & 8078.9 \\
\hline Aquaculture & 133.7 \\
\hline Fallow Land & 1783.1 \\
\hline Industry & 50.5 \\
\hline Marshy Land & 256.6 \\
\hline Plantation & 243.6 \\
\hline
\end{tabular}

Table-2 Land Use and Land Cover Area Calculations in 2000 of Pondicherry

\begin{tabular}{|c|c|}
\hline Categories & Area (in ha) \\
\hline Agricultural Land & 8649.16 \\
\hline Salt Pan & 86.208 \\
\hline Settlement with Vegetation & 9219.61 \\
\hline Settlement & 9239.6 \\
\hline Aquaculture & 138.76 \\
\hline Fallow Land & 2120.1 \\
\hline Industry & 134.673 \\
\hline Marshy Land & 232.78 \\
\hline Plantation & 385.1 \\
\hline
\end{tabular}


Table-3 Land Use and Land Cover Area Calculations in 2008 of Pondicherry

\begin{tabular}{|c|c|}
\hline Categories & Area (in ha) \\
\hline Agricultural Land & 7371.16 \\
\hline Salt Pan & 76.208 \\
\hline Settlement with Vegetation & 9457.8 \\
\hline Settlement & $10,761.71$ \\
\hline Aquaculture & 138.76 \\
\hline Fallow Land & 1432.1 \\
\hline Industry & 267 \\
\hline Marshy Land & 79.78 \\
\hline Plantation & 566.2 \\
\hline
\end{tabular}

Table-4 Land Use and Land Cover Area Calculations in 2014 of Pondicherry

\begin{tabular}{|c|c|}
\hline Categories & Area (in ha) \\
\hline Agricultural Land & 6214.24 \\
\hline Salt Pan & 76.208 \\
\hline Settlement with Vegetation & 1228.63 \\
\hline Settlement & $13,571.71$ \\
\hline Aquaculture & 138.76 \\
\hline Fallow Land & 1532.1 \\
\hline Industry & 301.01 \\
\hline Marshy Land & 79.78 \\
\hline Plantation & 467.12 \\
\hline
\end{tabular}

\section{Aquaculture}

Aquaculture occupied 133.7 ha during 1998 (Table 1) that has increased to 138.76 ha during 2014 (Table 4). Furthermore, from Figures 2-5, it can be clearly seen that aquaculture activities in Pondicherry have not in any way affected the agricultural activities. Similar research studies have been conducted by Krishnakumar et al. in 2011. The aquaculture occupied only in the brackish water area and not in other areas. Surprisingly, the aquaculture development is very minimum in Pondicherry region, wherein only 138 ha of brackish water shrimp farms land available have been developed from the available potential area of 800 ha. In Pondicherry region most of the farms are small with less than 2 ha. Very few farms are larger than 5 ha (Guidelines of Aquaculture Authority, 2001). If aquaculture is properly used in Pondicherry area then it is really a good source of income for local people. 


\section{Settlement}

The settlement spread over an area of 8078.9 ha during 1998, 9239.6 ha in 2000, 10761.71 ha in 2008 and 13571.71 ha in 2014. It is over a period of 8 years, the settlement area was increased because of population growth and urban development. A similar observation has been made by Nagamani and Ramachandran (2003) in their studies.

\section{Fallow Land}

It is defined as agriculture land, which will be taken up for cultivation is temporarily allowed to rest and remain uncultivated for one or two seasons but not less than one year. In the imagery fallow land appears yellow or greenish blue tone (Balak Ram \& Kolarkar, 1993). The fallow land in Pondicherry was occupied as 1783.1 ha in 1998, 2120.1 ha in 2000, 1432 ha in 2008 and 1532.4 ha in 2014.

\section{Settlement with Vegetation \& Industrial area}

The total area of settlement with vegetation during 1998 was 9189 ha, which has increased to 9219.61 ha in $2000,9467.8$ ha in 2008 and 1228.30 ha in 2014. The settlement with vegetation is steadily increased from 1998 to 2014. The industrial area is another land use area, which has increased from 1998 to 2014. In 1998, industrial area, which occupied 50.5 ha has increased to 134 ha in 2000, 267 ha in 2008 and 301.50 ha in 2014. The major land use classes by industrial areas converted the plantation areas of agriculture. It is to be noted that because of this industrial development, agriculture area was reduced. There are about 36 major industries, 105 medium scale industries and 6000 small scale industries are located in Pondicherry (Pondicherry Census Department, 1991-2001).

\section{Marshy Land \& Plantation}

Marshy land is the land where the water is at or near the surface and water stands for most part of the year. The vegetation here is permanently or periodically inundated by water. This category land occupies topographically low-lying areas. In the satellite imagery this category is seen in brownish tone. Marshy land occupied an area of 256.6 ha in 1998, 232.78 ha in 2000, 79.78 ha in 2008 and 79.78 ha in 2014. Marshy land drastically reduced from 1998 to 2014, wherein most of the land was converted to fallow lands (Fig 4). Plantation is described as an area under agricultural tree crops, which includes Coconut, Cashewnut, Arecanut, and other horticultural nurseries. Mostly Cashewnut and Banana plantation are seen here. The total area observed during 1998 was 243.6 ha and it has increased to 566.2 ha. Also, it reduced to 467.1 ha in 2014. 


\section{Suggestions}

- It is necessary to take action to control urban sprawl.

- Settlement should be constructed according to CRZ rules.

- Alternative livelihood option in terms of diversification, choices as well as supplementary income should be explored based on clear needs and feasibility assessment.

- The adverse impact of human activities needed to be curbed with proper policy measures ensuring sustainable use of natural resources and providing adequate conservation of sensitive and threatened ecosystem.

\section{Conclusion}

In Pondicherry, the major changes in land use inferred from the differences periods from 1998 to 2014, clearly reveals the extent of land use changes, its causes and consequences. The major change is the conversion of paddy fields to houses, factories and other built-up areas. Furthermore, the ssettlements have increased due to conversion of agricultural lands, fallow lands, mud and barren lands. The rapid increase in population slows down the growth of per capita income of Pondicherry and thereby the standard of living of the people gets affected to a large extent. This becomes a serious problem with regard to population growth, which outstrips the growth product. The main reason for conversion of agriculture activity to other activity is due to poor income from agriculture lands. Hence, the people migrate to work as laborers in industries. This in turn leads to deterioration in the availability of land and future growth of population, which would further worsen the land situation. Moreover, this will have alarming consequences on agricultural production. The overy crowding will mainly affect the productivity of land, wherein the agricultural income may decline and cause environmental damages. This in turn will affect the well-being of people, especially the poor. The other modes of income generation like aaquaculture, which has a better scope and should be constantly encouraged to protect other fields. The qualitative and quantitative aspects of the biophysical resources should be taken into account when introducing a new land use pattern in the area. The positive impact of aquaculture in the study area due to shrimp farming has considerably increased the land value. Before the commencement of shrimp farming, the land value in Pondicherry district was only about Rs.18, 000 to 20,000/- per ha. which has increased to about $1.8 \mathrm{lakh} / \mathrm{ha}(10$ times). Further, there were no major changes in the effort and in the annual fish landings during the study period, compared to periods before the commencement of intense farming activity. Employment opportunity has also increased due to aquaculture farming activity. Thus, aqua farming activity in this district seems to be a beneficial one. 


\section{References}

Anderson, R. R., Carler, V. \& M.Gnness, J. (1973). Application of ETRS data to Coastal Wetland Ecology with Special Reference to Plant Community Mapping and Typing and Impact of Man in $3{ }^{\text {rd }}$ Earth Resources Technology, Sate-1 Symposiums Vol.1, NASA, Washington D.C., pp.1225-1242.

Anusuya, B. \& Emayavaramban, V. (2017). Land Use/Land Cover Changes Detection of Kuthalam Block, Naagapattinam District, Tamil Nadu Using GIS, International Journal of Innovative Research in Science Engineering and Technology, Vol.6, No.5, pp.9426-9432.

Balak Ram \& Kolarkar, A. S. (1993). Remote Sensing Application in Monitoring Land Use Changes in Arid Rajasthan, International Journal of Remote Sensing, Vol.14, No.17, pp.3191-3200.

Barlet, D. S. \& Klemas, V. (1979). Assessment of Tidal Wetland Habitat and Productivity, In Proceedings of $13^{\text {th }}$ International Symposium on Remote Sensing of Environment, Vol.2, ERIM, Ann Arbor Michigan, pp.693-701.

Bennet, A. C. (1970). Crystalline Phosphates Produced by Interaction of Orthophosphate Fertilizers with Slightly Acid and Alkaline Soils, Soil Science Society of America Proceedings, No.40, pp.39-42.

Cha, L. (1996). Land Use Change Analysis for Agricultural Management - A Case Study of Tehsil Talwandi Sabo, Punjab, Journal of Indian Society of Remote Sensing, Vol.24, pp.115-123.

Gautam, N. C. (2004). National Land Use / Land cover Classification Cluma Publications Series-3, Hyderabad, 49p.

Gupta, M. C. (1997). Brackish water Aquaculture Site Selection using Remote Sensing and GIS and its Impacts on Environment, Proceedings of the Workshop Conducted by Rajiv Gandhi Centre for Aquaculture, Ganapathy R. and Kandan (eds.), pp.84-109.

Guidelines of Aquaculture Authority. (2001). Government of Pondicherry Report, Pondicherry Census Department, 1991-2001.

Howrah, P. J. (1984). Monitoring the Coastal and Inland Waters, Renewable Resource Management Application of Remote Sensing, American Socio of Photogrametry, Falls church, Vol.22046, pp.574-591. 
Kapetsky, J. M. (1987). A Geographical Information System and Satellite Remote Sensing to Plan for Aquaculture Development, A FAO-UNEP/GRID Co-operative study in Coasta Rica, FAO Fisheries Technical Paper, p.51.

Krishnakumar, P., Lakshmanan, C., Viveganandan, S., Jonathan, M. P. \& Muthukumar, S. (2011). Change Detection Studies in Coastal Zone features of Nagapattinam, Tamil Nadu by Remote Sensing and GIS, International Journal of Environmental Sciences, Vol.2, No.1, pp.213-221.

Krishnamoorthy, R. (1995). Remote Sensing of Mangrove Forest in Tamil Nadu Coast India, PhD Thesis, Anna University, Chennai, Tamil Nadu, p11.

Nagamani, K. \& Ramachandran, S. (2003). Land Use and Land Cover in Pondicherry using Remote Sensing and GIS, In Proceedings: Third International Cconference on Environmental and Health, Conducted by Department of Geography, University of Madras, Chennai, Tamil Nadu, pp.300-306.

Nayak, S. R., Gupta, M. C., Pandey, A. \& Triveni, C. R. (1988). Evaluation of IRS Data for Coastal Wetland Mapping in the Gulf of Katch, Scientific Note (IRSUP/SAC/AD/02/88), Space Applications Center, Ahmedabad, India, pp.99-119.

Palria, S. (1993). Potential Inland Aquaculture Site Selection Using Remote Sensing Techniques, In Proceedings: National Symposium on Remote Sensing Application for Resource Management with Special Emphasis on North Eastern Region, Guwahati, pp.226-230.

Raine, R. M. (1994). Current Land-Use and Changes in Land Use Cover Time in Coastal Zone of Thailand, Journal of Biological Conservation, Vol.67, No.3, pp.201-204.

Thanikachallam, M. \& Ramachandran, S. (2005). Remote Sensing and GIS Techniques for Monitoring the Coastal Environmental Changes: A Case study in Tuticorin Coast India, Map Asia-2005, GIS Development, pp.1-10. 